\title{
Front Matter: Volume 11739
}

, "Front Matter: Volume 11739," Proc. SPIE 11739, Fiber Optic Sensors and Applications XVII, 1173901 (4 May 2021); doi: 10.1117/12.2598620

SPIE. Event: SPIE Defense + Commercial Sensing, 2021, Online Only 


\title{
PROCEEDINGS OF SPIE
}

\section{Fiber Optic Sensors and Applications XVII}

\author{
Robert A. Lieberman \\ Glen A. Sanders \\ Ingrid U. Scheel \\ Editors
}

\section{2-16 April 2021}

Online Only, United States

Sponsored and Published by

SPIE 
The papers in this volume were part of the technical conference cited on the cover and title page. Papers were selected and subject to review by the editors and conference program committee. Some conference presentations may not be available for publication. Additional papers and presentation recordings may be available online in the SPIE Digital Library at SPIEDigitalLibrary.org.

The papers reflect the work and thoughts of the authors and are published herein as submitted. The publisher is not responsible for the validity of the information or for any outcomes resulting from reliance thereon.

Please use the following format to cite material from these proceedings:

Author(s), "Title of Paper," in Fiber Optic Sensors and Applications XVII, edited by Robert A. Lieberman, Glen A. Sanders, Ingrid U. Scheel, Proc. of SPIE 11739, Seven-digit Article CID Number (DD/MM/YYYY); (DOI URL).

ISSN: 0277-786X

ISSN: 1996-756X (electronic)

ISBN: 9781510643154

ISBN: 9781510643161 (electronic)

Published by

SPIE

P.O. Box 10, Bellingham, Washington 98227-0010 USA

Telephone +1 3606763290 (Pacific Time)

SPIE.org

Copyright (C) 2021 Society of Photo-Optical Instrumentation Engineers (SPIE).

Copying of material in this book for internal or personal use, or for the internal or personal use of specific clients, beyond the fair use provisions granted by the U.S. Copyright Law is authorized by SPIE subject to payment of fees. To obtain permission to use and share articles in this volume, visit Copyright Clearance Center at copyright.com. Other copying for republication, resale, advertising or promotion, or any form of systematic or multiple reproduction of any material in this book is prohibited except with permission in writing from the publisher.

Printed in the United States of America by Curran Associates, Inc., under license from SPIE.

Publication of record for individual papers is online in the SPIE Digital Library.

\section{SP|E. DIGITAL}

Paper Numbering: A unique citation identifier (CID) number is assigned to each article in the Proceedings of SPIE at the time of publication. Utilization of CIDs allows articles to be fully citable as soon as they are published online, and connects the same identifier to all online and print versions of the publication. SPIE uses a seven-digit CID article numbering system structured as follows:

- The first five digits correspond to the SPIE volume number.

- The last two digits indicate publication order within the volume using a Base 36 numbering system employing both numerals and letters. These two-number sets start with 00, 01, 02, 03, 04, 05, 06, 07, 08, 09, 0A, OB ... 0Z, followed by 10-1Z, 20-2Z, etc. The CID Number appears on each page of the manuscript. 


\section{Contents}

SESSION $1 \quad$ EXOTIC GUIDED-WAVE STRUCTURE FOR SENSING

1173903 Fabrication and application of single crystal fiber via laser heated pedestal growth system [1 1739-2]

$1173904 \quad$ Guideless optical sensing using space-time surface plasmon polaritons [11739-3]

\section{SESSION 2 FIBER OPTIC SENSORS AND APPLICATIONS}

1173908 Distributed dynamical temperature measurement of the rotor of small rotating machines using Fiber Bragg Gratings (FBGs) sensors [11739-7]

$11739 \mathrm{OB} \quad$ Atomic layer deposited $\mathrm{TiO}_{2}$ on optical fiber for $\mathrm{pH}$ sensing at $80^{\circ} \mathrm{C}$ [11739-10]

11739 OC Performance improvement of phase-optical time domain reflectometry ( $\Phi$-OTDR) based on wavelength diversity technique [1 1739-11]

11739 OD Development of femtosecond random gratings for fiber laser and sensor applications (Invited Paper) [1 1739-12]

\section{SESSION 3 HARSH ENVIRONMENT SENSORS FOR ENERGY APPLICATIONS}

11739 OE Metallic coating enabled optical fiber sensor for distributed corrosion monitoring [11739-13]

11739 OF Low-cost optical fiber based temperature sensor for real-time health monitoring of power transformers [11739-14]

$11739 \mathrm{OH} \quad$ Multi-parameter fiber optic sensing for harsh nuclear environments [1 1739-16]

11739 ol Optical-fiber based hydrogen sensing at high temperature using ALD coated oxide sensing layers [1 1739-17]

POSTER SESSION

11739 0J Redirecting sunlight for indoor illumination [11739-18] 
Proc. of SPIE Vol. 11739 1173901-4 Downloaded From: https://www.spiedigitallibrary.org/conference-proceedings-of-spie on 26 Apr 2023
Terms of Use: https://www.spiedigitallibrary.org/terms-of-use 